\title{
THE SOCIAL AND ECONOMIC SECURITY IN PROGRAMS OF POLAND'S LEFTIST POLITICAL PARTIES AT THE BEGINNINGS OF 1990s
}

\author{
Włodzimierz Gocalski \\ Wojskowa Akademia Techniczna \\ Arnold Warchał \\ Wojskowa Akademia Techniczna
}

\begin{abstract}
The authors' approach towards the main topic of this article is retrospective, in a sense of overviewing a politological account of changes occurred during transformation, based on Poland's contemporary history and in face of its political significance. It presents the position of the left-wing political parties on the issue of rebuilding the country's economic system in the initial period of transformation. The analysis refers specifically to the issues of social and economic security of Poland, at a given timeline with narrow political spectrum of the political parties. The problems discussed are characterized by the fact that the source database is deliberately limited to the documents and publications that are contemporary to the political events of those times. Indeed, some of the sources base is a chronicle like account of concepts' evolution in manner corresponding to description relating to times and values of interest. In the opinion of the authors, this allows for methodical individual evaluation of described processes, in reference to the facts analyzed and final synthesis manifestation, within the given processes and their outcome. Moreover, such approach is putting the security questions on proper fundaments of one of the original determinants.

Key words: politics, security, social security, economic security, political parties, social democracy.
\end{abstract}

\section{Introduction}

The consideration of security within political system's evolutionary process of various areas of interest, for society in general, will observe security in a broad spectrum, including the economic security and other corresponding, important for academic rationalization purposes. This is true of course, if the "rationalization" embraces the fundamental facts of its expression. Those however falling under an umbrella of discussion about political system may very quickly turn into ideology, where security as such may become second handed, even if general label still holds it as a major proposition. Usually, the phenomenon of issue's original factors are left out when ontologically speaking we can refer to the final construct in light of the above. However, scientifically speaking such constructs do not come out of oblivion. From the perspective of the twenty years passing, we can still relate, even today, to the moments when primary occurrence was not obscured by the passage of time, 
a process rather very rapid, since new events blur the interests in the "old" beginnings. The answer to question of: what led Poland to its extant situation after the political system change, may not be any longer propositional in nature but rather reactive or defensive; Whatever is still in a process of analysis, however, for the obvious reasons influences the debate on Poland's security. And security system, which it is creating as if throwing a big rock into the pond and waiting for a wave to hit the ground, may always be dangerous if the thrower doesn't move away before getting a splash.

The ideas and designs for new political system of Poland soon after the time of inception, and specifically references to problems of its social and economic security were not monolithic. That is, there were many "rock throwers". Simultaneously, one can notice on the outset that some of initial propositions were based on, more the "wishful thinking" than on the professional and calculated visions. This is obvious, since the political parties' programs must include both, the widest possible acceptance of a program, acceptance in ideological sphere of its active and possible constituency providing the votes, and pragmatic approach for the party leaders, who in practice will direct the narrow and still potential activities of possible government. Given of course, that political program will allow them to govern. This perspective also allows for an evaluation of a path that led Poland to its place in the European institutional structures. Referring to the beginning of political system's reconstruction, and economic and social subsystems, the authors argue that very focus on particular sources, facts that can be weighed, when connected will lead to a full view of necessary other outcomes, including those that determine the security status in both, different fragmented ways, and holistically.

Moreover, when especially analyzing different documents referring to original changes in the past, we can escape the very common subjective political stands. Those tend to put more weigh on specific ideological or other subjective perspectives that will change the entire evaluation of an issue discussed, making obsolete its objectivity (the authors keep it in mind in face of own analyses). For these particular reasons, the base source of descriptive items is consciously narrowed down to the documents and publications originating, for the most part, in times of issue development. Some of the sources are almost the chronicles of events as those were evolving. In democratic politics, the ontology of political systems, including its security outcome, can be described not just through the activities of a leader or leaders and citizens, but specifically through the documents, political agendas discussed and political programs described in spatial frames, where the programs are considered the "cause", and final vote the "effect" of relations. Perhaps upon the final evaluation, the outcome will still not be objective enough, for presentation of one and unchanging, unmoved, and hard view of what was the reality of contemporary history at the time when the cause events were occurring. Nevertheless, this is also true of "here and now" when the events are observed as they are happening, 
The social and economic security in programs of Poland's leftist political ...

not only when it comes to historical events. At least this is what hard science proves currently - in dimension where everything is in flux, since the motion of energy is also the motion of a creative process, the dogmatic "truth" is not only a fatality, but a desired fatality falling into one common denominator at best.

We are left therefore, with "political" cooperation on different issues. Its academic expression of a common denominator is social par excellence, and the truthfulness of the matter is very often not "objective", but rather inter-subjective. The authors remember that, hence their approach.

\section{Social democracy and social democracy of Poland}

Social democracy is one of the ideological categories in both, current political thought and political parties' spectrum - and in practice, movements, and orientations resulting from the deep divisions within the socialists' undertakings in general. Overall, it rejects the violent ideas, philosophical materialism, and Hegelian dialectic approach, of the typical German, and to some extent British discussions, of the revolutionaries against capitalism, heard amongst the Socialists and Marxists especially in the XIX, but latter in the XX \& XXI also common. Its main interest is the relation of "less privileged" and "underprivileged", to those "more privileged" or "over privileged", within free market economy and democratic process of governance, in States boasting of pluralistic society. The states in observance are of course the Germany or England, with the highest percent of industrial workers in Europe at the industrialization ascension, but later the same would apply to other European countries. Obviously, for some European elites, the rise in workforce needs and increase in numbers of workers would mean the less security for the capitalistic State and its government. This is true, given of course that the governing bodies want to enlist democratic course of political improvement of cohesion, within different groups and members of a society. This is especially true, if the elites want the State to survive without losing its state of belongings and power, what might promote violence and lead to the destruction of a country. Some of the XIX c. socialists were aware of the problem, and voiced their negative opinion before the totalitarian destruction of Russia and Germany put their hands of destruction on entire Europe.

Therefore, because some intellectuals, party leaders, and country elites of Western Europe, observe how the "revolutionary" propositions of Marxism and Socialism create a havoc of destruction in a "test country" - the Russia, they realize the need for a middle way. The middle way, if can be found, promote security of a country by bringing the opposites together - the capitalism and socialism, as is the case, and it has to be done for a security reasons. In this sense, there has to be built a security platform being not only in theory, but also in practice of internal balance between the owners and producers of an economic system. The social democrats, especially 
those in tuned with the economic elites, turned away from the idealism and aggressiveness of the previous revolutionaries. Furthermore, they realized the more realistic approach, taking the liberal truth that those who "have" must give a little, to those, who "have not" in a unification of needs at the level common for all, promoting the wellness of life. This is, if the system of many particular interests in economic arena, that enlists the help of a democratic process, will allow for the better control of society or a country as a whole. In a sense of liberal capitalistic pluralism, and not only if voiced by subjective economies of big actors, but in a sense of democratic liberalism based on economic needs and differences, can be unified in the middle way of economic endeavor. Therefore balancing and harmonizing activities of different economic interests and actors, what in a pragmatic sense enables creation of unison, and in essence is the sine qua none condition determinant of security in all other areas of State practices and social pragmatics.

Perhaps the continental protoplast of the current dimension of social democratic ideas and practices can be zeroed on German ideologist, Eduard Bernstein's ${ }^{1}$ canons of social democracy, discussed already at the end of XIX c., among the others. Yet, the social democratic politics as such, will have its exemplars in different countries, especially in Northern and Western Europe where it evolved into the "welfare state" paradigm, and not before but after the WWII, so long was the evolution of thought and matters. The views "naturally" found its way into the Central and Eastern European countries, after the "fall of communism" when the "test country" - Russia, and its forced into submission unwilling allies, were economically devastated by the Marxist-Leninist version of XIX and XX c. revolutionary theories. In its assumptions, this new version of liberalized socialism highlights the need for evolutionary changes, especially referring to the parliamentary methods as a way of bringing the workers and trade unions into the political process and governance. This may be allowed, as long as the fundamental means of economic exchange and production, its control packages, are in the hands of owners, both individual and corporate. In Poland this would imply, that after the initial political system changes in 1989, the issue of who controls what, would be of the outmost importance. Especially since the "control package" was still in the hands of the "ex-communists". What was the case surely then, and for better or for worse of those not connected to the post-communist power elite and its executive administration, on various levels of State control of the country and its society. Liberalization of this grip seemed mostly important for the rightist parties, but the leftist parties and the post-communist official understood it similarly, although for different reasons perhaps.

\footnotetext{
1 Cf.: Eduard Bernstein, Evolutionary Socialism, transl. by Edith C. Harvey, https://www.marxists.org/ reference/archive/bernstein/works/1899/evsoc/index.htm [29 X 2016]
} 
The social and economic security in programs of Poland's leftist political ...

This "liberal socialism" in democratic political process defines new agenda for economic security through focus on redistribution of national income, calling for greater social equality within the frames of mixed economy, without rejection of any of its canons that can be claimed to be at least partially socialistic in nature ${ }^{2}$. In this perspective, the political and economic programs are conglomerates of different concepts and ideas, often succumbing to modifications, in response to changes within the social environment ${ }^{3}$. In this sense, it shares the original motifs of communism but moves away from its "militancy" and "totalitarianism"4. It is obvious that just like any other ideological stances it goes through its own evolutions, and differentiations because of cultural and social approaches, as well as practices. In this instance, we can consider Poland's social democracy, as being usually connected in the past to the post-communism, but this would be true only for some social democratic parties, not all. Reason for this can be rationalized on the bases that country as a whole was leaning towards the West, after peacefully dealing with the Russian occupation. We can claim therefore, that the social democratic growth in Poland, generally and not particularly speaking, originating roughly in 1989, brings it closer to the "Western" views, than to the "Marxist" interpretations of socialism. Such was the case in Poland at the turn of 1980s and 1990s.

To expand on this view, we have to add the following comparative notes on Germany, since the social democratic notion of state's involvement in politics evolved initially in Germany. There is truth to the matter, that the unification of different views on economic security agendas, leading to one executive voice is difficult, as such. From the Polish perspective it seems that it was perhaps more difficult in a country famous for its liberum veto, than in a country famous in its past for "enlightened" absolute monarchy, leading at the end to evolution of its XX c. totalitarianism. Reason for this is that the core of legal decrees for its citizens and practice of law does not change, since in the country is understood as government and citizens tied by the governmental decree. Poland, as it was also the case at the end of 1980s, was under foreign political control and different decrees, also after the 1989. In the case of German unification - pushed towards the unification or surely influenced by the Polish Roundtable Talks, without which the "fall of the Berlin wall" would stay just the dream - the legality of all the state institutions was in its place upon unification. However, the legality of institutions in Poland changed. The truth of the matter, that not all Germans wanted this unification, is dimmed by the fact that most wanted it. In addition, most Germans ideologically did not differ so much, as the Poles at the same moment of its economic and political history. The social democracy in Germany had a much longer history and deeper impact on its internal cooperative

2 A. Antoszewski, R. Herbut (edits.), Leksykon politologii, Wrocław 1997, pp. 380-381.

3 Op. cit., p. 380 .

4 https://www.britannica.com/topic/social-democracy. 
policies, than social democratic suggestions found later, and copied in some instances too much, in Poland. Even if we exclude the long moment of social democratic government of the German Nazi Party - NSDAP, the prevailing view that it is the government controlling and balancing the economic processes falling under the notions of capitalism and socialism within democracy, did not change.

Yes, social democracy as in visions of German socialists was adaptive to both, the totalitarian German regime and the democratic German regime. It was not the same case in Poland. The opinions voiced on that matter by German scholars will differ, of course. For example, when discussing the unification problems of the Federal Republic of Germany and the Democratic Republic of Germany into a one unified German state, it was quickly pointed out: "But Poland without communist leadership still remained Poland. A transformed Hungary without communist power still remained Hungary" 5 . However, let's remember that the case of Germany is really more of a counter example of what was happening in Poland. For a long time its State security was hindered by the agenda of the past and foreign determinants, also by fragmented ideologically political scene, but especially by the 1980's destruction of economy, that lasted a decade. This was of course also true for a part of Germany, before the unification, but not for Germany after the unification, even if many problems were still to be solved, the capital was there to be used generously. Poland was not that lucky, it did not have its own capital, it had to rely on foreign loans and pray for foreign investments. And, so much, for the theoretical differences.

There are of course many differences and "peculiarities" when discussing the origins and evolvement of the Poland's social democratic parties ${ }^{6}$, however since it is their programs that we are mainly interested in, looking more for a common denominators of their programs than differences, we will leave those aside. Discussing the temporal moment of interest to us, the various political stands were influenced by complexities of both external and internal options. The public and state administration, was still controlled by the "ancient regime's" behavior and its rather undemocratic notion of power. This administration included also those participating or involved in 1981 coup by general Jaruzelski, what was unacceptable for some important Solidarity labor union authorities, unable to forgive the past sins of the round table discussants. The ideological "fight" between the leftist and rightist ideas was in its force. This made only more difficult, the very difficult process of political system's changes. No doubt, this influenced the internal security sphere, where "security" is considered on both the social and individual levels, and pertaining to economic processes. At the beginning, perhaps only the so-called "brotherhood"

5 Gerd Langguth, In Search of Security. A Socio-political Portrait of Today's Germany, Praeger Publishers, Westport, CT 1995, p. 78

6 Vide: Vit Hlousek, Lubomir Kopecek, Origin, Ideology and Transformation of Political Parties: EastCentral and Western Europe Compared, Routledge, London and New York 2010, pp. 15-40. 
The social and economic security in programs of Poland's leftist political ...

with Russia was in Poland dealt away quickly. This was an agreement done however, not because of domestic level discussions, but also on the international level, where Poland was one of the many interested parties.

In Poland's socio-political universe of the beginning of 1990's, several social democratic parties, sometimes estranged from each other, occupied its political scene. The most important ones, nonetheless, were the Social Democracy of the Republic of Poland (SdRP - Polish acronym of Socialdemokracja Rzeczypospolitej Polskiej), Labor United (UP - Polish acronym of Unia Pracy, small political party evolving from the Labor Solidarity), and Polish Socialist Party (PPS - Polish acronym of Polska Partia Socjalistyczna, historically speaking the reborn, oldest Polish socialist party). The origin and development of those parties were so different that their activities, not only that it did not promote any union with the others, but also stood on the way of any possible cooperation ${ }^{7}$. This becomes obvious, when we compare the SdRP and the UP. In case of those two, the background of the first was "post-communist" and the second stemmed out of Solidarity movement. Most of the social democratic movements, political groups, and organizations grouped around the Democratic Left Alliance (SLD). Its main force and leadership belonged to SdRP. Of those, not allied with SLD was only the UP, since the PPS rejecting the historical differences of the part decided finally to join this alliance ${ }^{8}$.

In consideration of the above differences, the presentation of the social democratic proposition for Poland in reference to security, considers then, the rebuilding process of economic and political system. The above-mentioned main parties would be the most representative for generalizations. However, it is really in political sphere, that its stances are the most important. At least, that is what the authors suggest, since the listed above had the biggest followings. This also become apparent when we review their views on industry, agriculture, structural policies, views on privatization, banking, monetary and fiscal policies, social, and the environmental policies, as is done below, and ask what happened to it today.

\section{The industry}

The industrial restructuring was one of the main issues the political parties had to cope with in their programs, not only the "leftist", but "rightist" as well. Poland, having one of the strongest industries of the Eastern bloc countries in the Soviet era, was almost stopped in its track of steady industrialization and development by almost a decade long General Jaruzelski's regime, foreign sanctions, and debts, it had to repay. There was a common agreement that the economy had to be liberalized

7 Cf.: Peter Gowan, The Global Gamble. Washington's Faustian Bid for World Dominance, Verso, London, New York 1999, pp. 260-291.

8 The Declaration of Alliance was accepted at the XXVI Congres of PPS , on November 1992. 
and switched from the state controlled to the open market economy, fast enough but also very carefully. If this was to be done too soon, the poorest social groups would have to pay the biggest burden of changes. This notion would prove to be the case, even two decades later, with Poland's economy still trying to catch up with the rest of Europe, and Polish citizens earning wages still far below their counterparts in the Western Europe. Of course, the issue is very complex and putting blame on anyone would prove to be very difficult to ascertain.

What can be proven, is that the social democratic programs of the parties mentioned differed in the respect of how to do it, but not that it should be done. There was a common agreement that this can be done only by modernization policies and adaptation to free market economy agenda. The re-industrialization program was understood to be obligatory. The government's role was seen in its moving away from the destructive activities towards the state owned companies, yet at the same time, its protection of those during the times of transformation was considered also essential. The free market conditions should be the same for all the actors involved, otherwise, the state and cooperative establishments will have little chance to compete and evolve through competition. Therefore, the aim of state policy in such environment had to be focused on a thorough reconstruction of the outdated structure of Polish industry, integrating it into the world economy market with benefits for state, cooperative, and privately owned companies ${ }^{9}$. Such a change had to be done carefully and rather slowly, since quick and radical changes within the body of infrastructure of the post-communist industry was very treacherous or impossible without great economic loses and dangerous social upheavals. The changes to State's industrial policies, as most social democratic parties understood it, had to be gradual. Its role was seen as a twofold activity, in a protection of the free market economic system and the industry within it, and stimulating the functioning of this market economy and its various mechanisms. In practice, this would involve the support in development of those branches of economy that carried the biggest potential for modernization, creating the technological progress, reducing unemployment, and those that are at the same time in hands of the state ownership ${ }^{10}$. In the general opinion of the social democrats, the state interventionism must be largely present, and this included planning and providing economic parameters for the raw materials and certain other products, direct subsidies when necessary, countervailing duties, restoration of market balance with government procurements, or development of economic programs for particular areas related to social needs ${ }^{11}$. At the same time

\footnotetext{
9 Program Decree of the First Labor United Congress, Warszawa - January 1993.

10 The Socio-Economic Program of the SdRP, Warszawa, Maj 1991.

11 The Program Documents, approved by the XXV Congress of the Polish Socialist Party, Warszawa, October 1990 .
} 
The social and economic security in programs of Poland's leftist political ...

investment opportunities for the foreign capital had to be promoted, with the legal counterbalancing against economic exploitation.

\section{The agriculture}

It was a prevailing view for the leftist parties overall, that the agriculture was that branch of economy that need very special attentions and any policies referring to farming and countryside had to be carefully thought-out, since progress in that area cannot occur without the government's help. Especially the help with financial actives and provisions for the modernization processes were necessary, according to the opinions of the most social democrats in the 90's. The agriculture was to be provided with the preferential credits, for production, farms modernization, protection against imported products - especially those subsidized by the exporters, extending and making more flexible the state interventionism in buying the agricultural products, and promotion of agricultural surplus products for export. The Social Democracy of the Polish Republic, the Polish Socialist Party, and the Labor United, were similar in their thinking about this issue. Extending the modernization processes, the steady and stable increase in development of farming productions and increasing the level of profitability of agricultural production, was also an important agenda, since treated as the base for modernization.

The pressing on those changes, modernization and particular production specializations, as well as providing initiatives for the enlargements of farming areas was considered the prerequisite of conditions for stimulating growth in agricultural productivity, what is apparent in the programs of the Labor United ${ }^{12}$. In the various opinions, Polish agriculture was supposed to comprise of different aspects but in unison of all. In addition, in the SdRP view, the land exchange and purchase, including the capital and workers interchange, was to be free. The ideological and doctrinal approach towards the privatization in agriculture was considered a hindrance and needed liberalization, keeping in check the equality of all ownerships within and between different sectors of industry. The common call for privatization was a way of fixing low levels of cash flow within this sector of country's economic fields.

The program of the SdRP stressed that it was also necessary to allow the ingrowth of the agricultural cooperatives and state farms into the market economy, and help in natural structural and ownership interchange, without the need for use of political or administrative methods ${ }^{13}$. The PPS proposed on the other hand, that the local governments should control the agricultural cooperatives and the State Farms Holdings (PGR - Polish acronym for Polskie Gospodarstwa Rolne). There was no disagreement however, in regards to understanding that land exchange would have

12 Program Decree of the First Congress of Labor United, Warszawa 1993.

13 The Socio-Economic Program of the SdRP, Warszawa, Maj 1991. 
to be liberalized in general, allowing farmers the expansion of their production. In agricultural party programs, the changes in that field, those changes necessary, were supposed to lead to the structural change in the future of Polish countryside, in a sense of adding the created strong, autonomous, highly effective peasants' farms, into the prosperous free market economy face. Bothe, the SdRP and the PPS believed that this could be done at the steady and evolutionary pace.

\section{Structural policies in party programs}

The structural policy in the social democratic parties' programs targeted and was oriented on the mixed model of economy. Those parties, generally and in principle, were promoting the social model of free market economy, what simply implies the combination of capitalism and the social protection of the poorest, and inclusion of state, local and other cooperatives in the open trade relations. This acceptance of different actors in economic arena was based on its pluralistic vision, however was also protective of some old communistic era entities, and those controlling it. This is why one could also find disagreements between those three social democratic parties: SdRP - was comprised of ex-Polish People Workers Party officials. The UP - Labor United - was originating from Solidarity movement. The PPS - Polish Socialist Party - was a "revived" old socialist party with longest tradition in Poland, historically speaking, of course, since it was founded in 1892. Therefore, the social democratic label was not enough to bring them together on many issues, not only the structural policy. The PPS, for example, had asserted that that the non-private business should play a greater role in economic process, than it is common in the Western economies. This view is more an ideological (historical) stance, than views on the subject presented by the SdRP. Practically, the SdRP was still controlling the economy because of the "know-how" they had from the past, through the nomenclature of directors and managers from the "ancient regime". The UP - Labor United is still different story. Stemming out of Solidarity movement, it was closest to the workers in a sense that understood the labor needs and considered important the protection, to some extent, of the "socialist ways" in regards to work force. Those different origins presented different ideas in regards of the "public interest" - defined in various terms, because of their different leaders and their background. Nonetheless, they did believe at the beginning, what is also noticeable in their programs, that (for different reasons) the reconstruction of the ownership, in order to serve efficiently Poland's new economic system, should be a long-term project, and carefully thought out. The role of the government was to specify the particular economic undertakings and select the branches of economy that have crucial importance for the country. The employees of state-owned enterprises were to be included in the decision making process (through the referenda) about the form of ownership for 
The social and economic security in programs of Poland's leftist political ...

their establishments, since they are the most interested, was the case presented by the SdRP. All of these groups have opted for extensive employee self-government in their respective factories or enterprises, through trade unions, regardless of the type of ownership for which they were working.

\section{Privatization issues}

The privatization of national property was that area of discussion, where the expression and appropriate relationship with the other economic areas, had to be closely linked to the proposals within structural policies' frames. They did advocate, in general, the privatization of different economic sectors, however, under specific and important protective conditions. The Labor United accepted it, as a "natural process" of the free market economy, and its enforced "organic" speed of growth considered as a symbiotic connection to other areas of economy. The most important goal, in view of organic tempo of privatization was the creation of new private enterprises. The most favorable conditions for buying off from the old state ownership initially should be created for the employees. The simplicity of reasoning in this fashion was rather obvious; the buyers would have to reclaim the enterprises at the most challenging moment of economic difficulties for the given enterprise ${ }^{14}$. The SDRP and PPS have also seen the need for privatization. Their main focus was on the small and medium-sized enterprises (what was called in Poland the "small privatization"), in some instances returning to old family ownership or changing into a family ownership, especially in regards to enterprises where the high management costs were unprofitable for the State, and its ownership would seem not pragmatic.

All of the analyzed groups strongly opposed the uncontrolled, direct privatization or one done in view or because of ideological perspectives, and based on simple political motivations. The SdRP and PPS, were both against the free giveaway of shares in State enterprises, or similar method of generating the future citizen shareholders. In addition, the UP was opposing the idea of universal, national privatization, arguing that this paradoxically in a long run could open the door for accumulation of assets in hands of the few, including property that was previously public, but creating poverty for the rest. This would be the opposite of the goal intended, because the lack of control in the latter part of production and distribution would undermine the result focused on universal wealth.

The SdRP believed that the state factories, those especially that are most modern and most effective, should not be privatized at all. The privatization was to involve only those industrial enterprises and facilities that are ineffective and poorly run. It should be an alternative, but not a voluntary valuation of the companies, and not

14 Program Decree of the Labor United Congress, Warszawa 1993 . Cf.: Decree of RK UP, approved on March 21st. 1993, concerning the universal privatization and concerning the re-privatization. 
a bargain for future shareholders who could purchase the most valuable elements of state economy, with the least effort. The Polish Socialist Party establishment members believed that the most appropriate ownership transformation of the Polish economy would be the creation of cooperatives and companies under employee ownership (in accordance with the will of workers or the crew).

The issue of the legality of privatization was also evaluated in party programs. Many of the party leaders and their followers had rather skeptical assertions on that matter. As some believed, instead of positively restructuring the system, it would create many unknowns, including the raise in sense of uncertainty and instability for the employees. Nonetheless, the provisions of integrity in reference to confirmation of necessities stemming from the reform of agricultural progress, and nationalization, with the particular legal acts, were deemed necessary. Yet, it would be created for first time in the postwar period ${ }^{15}$. In a new, democratic and liberal society, however, the different remedies should be prepared and applied only to cases where there is an infringement of the rights of the past ownership. The "returns" to old ownership could be done not in a form of estates, building and lands returns, but rather in a form of equity vouchers for the purchase of shares in privatized companies. This compensation however, could not prejudice the strategic interests of the State ${ }^{16}$.

\section{The fiscal and banking policies}

In the area of fiscal, banking and monetary policies the general trend was to mitigate the system and start the liberalization process in general. The changes in credit policies were considered necessary, and those were supposed to be done through lowering of interest rates on investment loans leading to creation of preferential credits for export products, agriculture improvements, and also, for housing development ${ }^{17}$. Growth of the money supply for the economy was understood to be a necessity for investment purposes but not for consumption goals. Any quick budget liquidation attempt (for example, by state spending withdrawal from the social help) was not considered reasonable, since leading potentially to economic and social tensions in a society that was already poor and unsure of its future. The high budget deficit could not be avoided, as was understood by the social democratic parties; therefore, it was believed that it could be financed by public deficit and foreign loans, and foreign currency reserves ${ }^{18}$.

\footnotetext{
15 The Socio-Economic Program of the SdRP, Warszawa, Maj 1991.

16 SLD, Our program for Poland, Warszawa, Maj 1991. Cf.: Decree of RK UP, approved on March 21st. 1993, concerning the universal privatization and concerning the re-privatization.

17 SLD, Our program for Poland, Warszawa, Maj 1991.

18 Op. cit. Cf.: Program Decree of the Labor United Congress, Warszawa 1993.
} 
The social and economic security in programs of Poland's leftist political ...

The tax system should become part of the industrial stimuli and economic development but also should guarantee the implementation of the principle of equal opportunities for all citizens. At least this was the Polish Socialist Party's idea. Maintaining of the tax raises based on salary increases was considered antimotivational and destructive to individual wealth. Increasing tax affliction should be limited to the effective enforcement of tax claims, in views of SdRP and PPS ${ }^{19}$. The principle of full universal taxation in a progressive form of tax burden for different wages and revenues was considered to be the best norm by those parties $^{20}$. There was also a proposal of taxation simplifications and lower taxes for small services and artisanship, yet increase in taxes for the luxury goods (raising the tax burden for the richer part of society). The changes in taxing policies were to go in hand with forced savings in the budget expenditure, excluding however the areas of social politics. When it comes to tax incentives, those would be available for undertakings in the areas of investments and economic reconstruction. Tax deductions should be also possible for those citizens' submissions given to social help institutions. Approach towards the monetary policy of these parties was not seen only through the prism of governmental agenda and its achievements in this area, since it had to be done through international arena, among the others. The convertibility of money (even in limited extent) was considered fundamental in principle, and necessity for the market economy that Poland wanted to participate in on the international level. However, the changes were supposed to be brought about without extensive (also in time duration) preparations, what resulted in number of differences of the social democratic parties' programs, and leveled propositions. The partial interchangeability of the Polish Zloty (PLN later) had to be redeemed by the establishment with overpricing of the Dollar and other Western currencies. Such an approach, as the Labor United foresaw it, would be a reason for deep recession ${ }^{21}$. What was also understood, the changes would require, instead of rigid course maintenance the introduction of better fluidity into the course rates. This, according to SdRP, should positively and significantly affect the trade balance. The PPS proposed still different notion, a departure from the full internal convertibility of "Zloty", because in the economical state Poland was in, it could not sustain a confrontation with the more efficient economies of the West ${ }^{22}$.

19 Solidarity United, Program thesis for discussions, [in:] I. Słodkowska, Programy partii ... op. cit. (part 2), p. 175

20 Op. cit.

21 Op. cit., pp. 174-175

22 Polish Socialist Party Program Documents. The Theses of the Alternative Economic Program, approved by XXV PPS Congres, Warszawa, October 1990 . 


\section{The social policy in party programs}

The social policy in the programs of the leftist parties traditionally occupied a significant place, and this was the same case for many parties. In the substantive parts of the programs, their social policy propositions are comparable, at least for the parties discussed, where their ideas were centered on the State, as an important actor and playing the main role is preparation of an extensive system of social security for its citizens. Therefore, the Poland's social democratic parties were all in favor of the principle of universal and compulsory social insurance. Parallel to this system there is an allowance made for the insurance companies operating in similar or additional fields, and other independent and voluntary insurance services. Mandatory pension insurance scheme should ensure the provisions for life on a level appropriate for a decent living. The parties did accept the need for reforming health care, even if moving closer towards the commercialization of certain services and market pricing for pharmacological remedies, however, those would be valued appropriately with due compensation, as both the SdRP and PPS agreed. Insurance company should pay for the costs of medical treatment in various State-owned, cooperatives, and other types of medical facilities. People uninsured, requiring the medical help or use of medical services, were supposed to be reimbursed from the funds of social welfare, the social maladies were supposed to be treated free of charge at the expense of the State. What was the proposition of the Polish Socialist Party. The Labor United believed, as was visible through their program, that there should be a completely free health care for children, adolescent and pregnant women.

The ideas stressed out in the social democratic programs, implied that social policy cannot be a form of alms but should form an integral part of economic policy, so that every citizen could pursue their constitutional rights. This implication was made by the PPS. Special protection should be directed towards the groups of people, who due to biological conditions or vital los may have difficulties in the implementation of their rights. Funds for social assistance should come from the central budget and municipalities, and the social security funds. There should also be created a specific partnership in this system of values and practical propositions, where the social democratic groups did consider the charitable non-governmental organizations, churches, and religious groups, playing important role. In their social programs, the social democratic parties understood that there has to be also resolved the problem of unemployment, including the measures for its limitations, providing free access to all levels of schools, leisure for youth, and construction and housing projects for the less advantaged. 
The social and economic security in programs of Poland's leftist political ...

\section{The ecological policies}

The environmental protection was the area in which differences between the parties, rather frequent for whatever reasons, were brought into some unison. This is obvious regardless of their programs, and furthermore, regardless of political orientations in Poland. Only on the value of statutory documents, or volume of those, we can notice some differences in question, just in reference to the party programs, but not the perspectives on ecology. In the aforementioned programs, we can run across references to concrete and complex studies on environmental protection. Sometimes, in the programs we see this issue discussed only in general terms, and sometimes, as a residue of discussion in the areas of industry, agriculture, or others. This would mean approval of the question of how to deal with this issue. Even if the question sometimes would be forgotten, when the given party was asked about ecology, surely they would show a positive interest, giving the most general answer.

When we look at their programs from the initial and oldest periods of their activity, we see diverse suggestions in the area, yet under one common denominator - need for improvement. Polish Socialist Party had perhaps most specific and interesting proposition, since it called for implementation of rigors for industry and economy in general, that would focus on regeneration of the environmental condition. Overall, it was understood that the ecological codex should be created, as well as the institutions of the ecological police and the ecological tribunal. The central State governments was given the responsibility of proper environmental protection legal solutions development, and in practice establishing the limits, among the others, on the levels of harmful production, as well as the levels of legal limits of harmful emissions. The other duties would include designing and starting the process of damage recovery in the ecologically most run down parts of the country. In this ecological effort, the citizens and institutions should have the right of participation and voicing their needs.

The ecological decisions should be taken by the way of a referendum. This would require the need to develop environmental education, as well as designing and promoting solutions compatible with the requirements of the environmental protection. Residents living in contaminated or unhealthy environment, as it was proposed, were to have the right to compensation on the same basis as in the case of occupational diseases and accidents at work. The environmental policy was a subject of the same importance as the economic development and reconstruction of the political system ${ }^{23}$. The Labor United proposition advocated that the environmental protection should be regarded as one of the priorities of State policy. This would imply the effort to change the attitudes and activate within society the proper approach towards the protection of environment. The education in this field, even by

23 PPS, Program Documents, approved by the XXV Congress of PPS, Warszawa, October 1990. 
modification of the school curriculum, promoted by media encouragement, was aimed towards creation of greater interest on the issues of ecological protection. The social democratic parties' programs were in agreement that the natural resources and the natural environmental fields should be subjected to the constitutional protection, because economic development cannot evolve by the destruction of environment ${ }^{24}$. It was also understood, that the entry of the materials and goods constituting an ecological threat, should not be allowed to Poland ${ }^{25}$.

\section{SUMMARY}

Poland at the turn of 1980s and 1990s was coming to an age of a long awaited democratization and socio-political changes. The political parties and political reality then, were creative of the new democratic platform and democratic involvement of its citizens $^{26}$. Not many of the social-democratic ideas survived to-day as is usually the case with the ideas, political programs, and doctrines. Reality check button is always turned on, when it comes to market value, profits to be made, and own capital to be made, on a subjective level. How and how many of the ideas change, only because the people promoting them also change, could be a theme of another analysis itself, but it is hard to estimate. Between the intentions and the effects sometimes there is a long temporal and deep spatial gap.

We can rather openly state, that the economic environment and Poland's struggle in the free market economy, controlled by the West in its details, of which Poland had little knowledge of, most definitely determined the wealth of many social groups, especially those from the lower parts of society. Such determinant had rather a negative effect on those most disadvantaged. This is another issue, and does not necessarily directs us towards the intentions, that we have observed in the social democratic parties' programs from the outset of changes, what was the main theme of this article. Needless to say at the beginning Poland was treated rather as an object of an economic and financial interests than as the equal participant in the free market economy. Surely Poland's debts and loans had important impact in this case. The effects of this reality check, was slow progress, and inability of the social democratic ideas to come into full force. The different state authorities and political parties enjoyed and participated in this progress, but not necessarily this was true of the citizens in general, especially those disadvantaged, also because of the

24 Declaration of the Social Democracy of the Polish Republic, Warszawa 1994

25 SLD, Our program for Poland, Warszawa, May 1993; The SdRP, until the 1993 did not present the unified ecological program. Its agendas in this matter at that time would be intertwined with the industrial and economic policies, or seen through the SLD programs.

${ }^{26}$ Cf.: Ryszard Herbut, Parties and the Polish party system: the process of structuring the political space [in:] K. Cordell, Poland and the European Union, Routledge, London \& New York 2000, pp. 86-105 
The social and economic security in programs of Poland's leftist political ...

governments in which the social democrats also played a role in different times. For those, to whom the social democratic ideas were directed to, the progress was slow and occupied by many hardships. This is common after all, in the politics where the democracy and economy meet.

The political and social pragmatic discussion in Poland was happening in times when democracy itself in many other places has evolved into many different models of political interaction. Some models, as it is suggestive to point towards the German and similar Western type of democracies, have been evolving already for the long time, having its roots in Marxist and Socialist ideas of the XIX c., taming them; the others, like the republican version of liberalism of the United States, even a hundred years earlier. What implies is that the, so-called, Western democracies, had a much longer time to develop into its contemporary form being constantly overflowed with wealth, and WWII did not changed it, as was the case with Poland. This allowed intertwining of the political ideas, and ideologies, in the arena where the economy and politics meet and decide on the best model of cooperation between the different leaders from different fields of social and economic activities.

Its effect is the current dominant in the Western Europe, of the social-democratic model of a free market economy that in large part is known as the "welfare state". The wealth in those countries became the fundamental of its national interest, the wealth of the average individual considered the strength of the nation. This seems to be true of Germany, for example. It might be added that some of the "democratic" institutions in those "old democracies" have changed their orientation because of the capitalistic economic system and ideological persuasions ${ }^{27}$. This change is not necessarily positive, because of the nature of globalization and political ideologies of the elites changing the "democratic process" into "procedural democracy" 28 and finally into an oligarchy. In the nationalist societies - with the social democratic parties or without them - what is the case in some Western democracies, for example like Germany, the "process" may became less democratic, in a sense of ideological governmental control of the "minds and wallets", of its citizens. In the more liberal societies, the market economy "regulates" those away from the decision making process, where it really matters ${ }^{29}$. Poland is still between those two predicaments, and hopefully will find its own road to progress and modernization, within the global economic market, since in those realms it still lags after the economic wealth of its western neighbors.

27 Cf.: M. Gilens and B.I. Page, Testing Theories of American Politics: Elites, Interest Groups, and Average Citizens, [in:] "Perspectives on Politics", Volume 12, Issue 3, American Political Science Association September 2014, pp. 564-581

28 Vide: G. Klosko, Democratic Procedures and Liberal Consensus, Oxford University Press, New York 2003

29 Vide: M. Gilens and B.I. Page, op. cit. 
The economic programs of the social democratic political orientation did not differ essentially from the programs of other political groups and parties of that time, on the Polish political scene. This convergence was contained in the absence of a clear concept of the objectives of cohesion, economic solutions presented in general and at the same time giving practical solution on the issues of importance. This resulted in ideological polemics with government, mostly without any real input into the socio-economic system, and was rather hardline, forcing own opinions on all matters, without acceptance of a possibility of alternate, and perhaps better economic solutions.

However, the ideological agreement between the three parties was determined by the following views: 1 . Notion of the comprehensive range of social security programs should be applied. 2. The social-democratic ideas should lead in reality towards the welfare state system. 3 . The party programs should be addressed to particular social groups and professional fields. 4. The social-democratic programs, some of those can be similar to those of the government, and others must be the alternative to State solutions. 5. There was an understanding that the social democratic party programs are rather in opposition to dominant elites ideas that is the, liberal solutions; We must still remember, that the difference in practical solutions were more. One of the main difference stemmed out of the real control of the economic process. This, as we know, not always is democratic, especially when we think of new free market economy possibilities that opened for the both, the ex-communist officials and the ex-Solidarity leaders during the "round table talks". During the talks of the leaders, the common folks are usually forgotten. And this is why the social-democratic ideas can not evolve quicker than the economy itself, from which the social programs can take their energy.

Table 1. The social-democratic party agendas in Poland

\begin{tabular}{|c|l|l|l|}
\hline $\begin{array}{c}\text { SELECTED } \\
\text { AREAS OF } \\
\text { ECONOMIC } \\
\text { POLICIES }\end{array}$ & $\begin{array}{l}\text { SOCIAL DEMOCRACY } \\
\text { OF THE REPUBLIC OF } \\
\text { POLAND }\end{array}$ & LABOR UNITED & $\begin{array}{l}\text { POLISH SOCIALIST } \\
\text { PARTY }\end{array}$ \\
\hline Industrial policy & $\begin{array}{l}\text { Adaptation of factory } \\
\text { production to free } \\
\text { market rules. Equality } \\
\text { for different industrial } \\
\text { producers. }\end{array}$ & $\begin{array}{l}\text { Adaptation of factory } \\
\text { production to free } \\
\text { market rules. Equality } \\
\text { for different industrial } \\
\text { producers. State } \\
\text { supports these elements } \\
\text { of industry that provides } \\
\text { the fastest growth, } \\
\text { development potential, } \\
\text { and reducing the } \\
\text { unemployment. }\end{array}$ & $\begin{array}{l}\text { State interventionism, } \\
\text { dotations, state } \\
\text { planning of the } \\
\text { activities for industry } \\
\text { sectors, steady } \\
\text { development. }\end{array}$ \\
\hline
\end{tabular}


The social and economic security in programs of Poland's leftist political ...

\begin{tabular}{|c|c|c|c|}
\hline $\begin{array}{c}\text { SELECTED } \\
\text { AREAS OF } \\
\text { ECONOMIC } \\
\text { POLICIES }\end{array}$ & $\begin{array}{c}\text { SOCIAL DEMOCRACY } \\
\text { OF THE REPUBLIC OF } \\
\text { POLAND }\end{array}$ & LABOR UNITED & $\begin{array}{c}\text { POLISH SOCIALIST } \\
\text { PARTY }\end{array}$ \\
\hline $\begin{array}{l}\text { Agricultural } \\
\text { policy }\end{array}$ & $\begin{array}{l}\text { Special treatment and } \\
\text { state support in the } \\
\text { modernization processes. }\end{array}$ & $\begin{array}{l}\text { Special treatment } \\
\text { and state support. } \\
\text { Diversification and } \\
\text { modernization } \\
\text { processes. }\end{array}$ & $\begin{array}{l}\text { Equality of the } \\
\text { agricultural sectors. } \\
\text { Evolutionary progress. } \\
\text { Tariffs against foreign } \\
\text { produce. }\end{array}$ \\
\hline Structural policy & $\begin{array}{l}\text { The social free market } \\
\text { economy with mixed } \\
\text { property. }\end{array}$ & $\begin{array}{l}\text { The social free market } \\
\text { economy with mixed } \\
\text { property.. }\end{array}$ & $\begin{array}{l}\text { The social free market } \\
\text { economy with mixed } \\
\text { property... }\end{array}$ \\
\hline $\begin{array}{l}\text { Privatization and } \\
\text { Reprivatization }\end{array}$ & $\begin{array}{l}\text { Privatization determined } \\
\text { by economic factors. Re- } \\
\text { privatization only in the } \\
\text { case of infringements on } \\
\text { the past rights of owners } \\
\text { and in the form of state } \\
\text { vouchers. }\end{array}$ & $\begin{array}{l}\text { Privatization determined } \\
\text { by economic factors. Re- } \\
\text { privatization only in the } \\
\text { case of infringements on } \\
\text { the past rights of owners, } \\
\text { and on limited rights. . }\end{array}$ & $\begin{array}{l}\text { Privatization as } \\
\text { an alternative for } \\
\text { ineffective elements of } \\
\text { industry. Negative view } \\
\text { on re-privatization. }\end{array}$ \\
\hline $\begin{array}{c}\text { Fiscal and } \\
\text { Banking Policy }\end{array}$ & $\begin{array}{l}\text { Increase of the money } \\
\text { circulating in the } \\
\text { economy based on } \\
\text { budget deficit and needs, } \\
\text { including credit policies. } \\
\text { Taxes dependent on the } \\
\text { need of development } \\
\text { stimuli with broad } \\
\text { packages of reliefs and } \\
\text { deductions. }\end{array}$ & $\begin{array}{l}\text { Increase of the money } \\
\text { circulating in the } \\
\text { economy based on } \\
\text { budget deficit and } \\
\text { needs, including credit } \\
\text { policies. Reliefs and } \\
\text { deductions. }\end{array}$ & $\begin{array}{l}\text { Changes in credit } \\
\text { policies, increase in } \\
\text { budget deficit and Tax } \\
\text { system stymulating } \\
\text { industiral growth. } \\
\text { Priniciple of equality } \\
\text { in taxes and progresive } \\
\text { taxation. . }\end{array}$ \\
\hline Monetar & $\begin{array}{l}\text { Country's currency } \\
\text { interchangable within } \\
\text { international economic } \\
\text { community and foreign } \\
\text { currencies. }\end{array}$ & $\begin{array}{l}\text { Change of the exchenge } \\
\text { rates betwen Złoty } \\
\text { (PLN) and Dollar in } \\
\text { favor of Złoty (PLN). }\end{array}$ & $\begin{array}{l}\text { Revoking of the } \\
\text { internal exchange rights } \\
\text { for Złoty (PLN) }\end{array}$ \\
\hline Social policy & $\begin{array}{l}\text { An extensive system of } \\
\text { social security. Common } \\
\text { health insurance and } \\
\text { retirement pension for } \\
\text { everyone and mandatory. } \\
\text { Social care under the } \\
\text { scrutiny of the state and } \\
\text { nongovernmental bodies. }\end{array}$ & \begin{tabular}{|l|} 
An extensive system of \\
social security. Common \\
health insurance and \\
retirement pension for \\
everyone and mandatory. \\
Social care under the \\
scrutiny of the state and \\
ongovernmental bodies..
\end{tabular} & $\begin{array}{l}\text { Extensive system } \\
\text { of social welfare. } \\
\text { Compulsory insurance } \\
\text { in all areas. Social help } \\
\text { controlled by the state, } \\
\text { with help of the varius } \\
\text { charity organizations. }\end{array}$ \\
\hline $\begin{array}{l}\text { Environmental } \\
\text { policy }\end{array}$ & $\begin{array}{l}\text { Little or none } \\
\text { environmental policies, } \\
\text { but understood as } \\
\text { necessary. }\end{array}$ & $\begin{array}{l}\text { Little or none } \\
\text { environmental policies, } \\
\text { but understood as } \\
\text { necessary. }\end{array}$ & $\begin{array}{l}\text { Extensive ecological } \\
\text { program. }\end{array}$ \\
\hline
\end{tabular}

Own analysis based on party programs. 
In General, we can conclude that the economic development concepts proposed by the Polish left were bound towards the construction of a social market economy with continuation of slower changes, rather than fast. This, as their leaders and members believed, should be done in different stages. Reconstruction of the system should be accompanied by considerable social cover guaranteed by the State, together with a compatibility with the principle of social justice, spreading the cost of reform. They were rejecting the liberal economic concepts in view that those will too much differentiate economically the society. In the political area, they had, of course, different opinions about the Poland's postwar history. And those and other differences are still discussed in Poland to-day.

To this summary we can also add the table 1, below generalizing on the common denominators, and sometimes differences of the parties described. This overall view of their programs, has to be taken nonetheless with more specific ideas, especially by those parties that participated also in government. Such was the case especially of the SdRP, but not of the other parties.

\section{BIBLIOGRAPHY:}

[1] Antoszewski A., Herbut R. (edits.), Leksykon politologii, Wrocław 1997.

[2] Bernstein E., Evolutionary Socialism, transl. by Edith C. Harvey, https://www.marxists. org/reference/archive/bernstein/works/1899/evsoc/index.htm

[3] Condell K., Poland and the European Union, Routledge, London \& New York 2000.

[4] Deklaracja Socjaldemokracji Rzeczpospolitej Polskiej (Declaration of the Social democracy of the Polish Republic), Warszawa 1994.

[5] Dokumenty programowe, uchwalone przez XXV Kongres Polskiej Partii Socjalistycznej (Program Documents, approved by the XXV Congress of the Polish Socialist Party), Warszawa - October 1990.

[6] Garbarski L., RutKowski I., Wrzosek W., Interwencjonizm państwa na rynku, „Monografie i Opracowania IFGN SGH", Warszawa 1994.

[7] Gilens M. and Page B.I., Testing Theories of American Politics: Elites, Interest Groups, and Average Citizens, [in:] "Perspectives on Politics", Volume 12, Issue 3, American Political Science Association, September 2014.

[8] Gowan P., The Global Gamble. Washington's Faustian Bid for World Dominance, Verso, London, New York 1999.

[9] Herbut R., Parties and the Polish party system: the process of structuring the political space, [in:] Karl Cordell, Poland and the European Union, Routledge, London \& New York 2000.

[10] Hlousek V., Kopecek L., Origin, Ideology and Transformation of Political Parties: EastCentral and Western Europe Compared, Routledge, London and New York 2010.

[11] Jако́вік W. (edit.), Zmiany strukturalne: Gospodarka i społeczeństwo, Instytut Studiów Politycznych PAN, Fundacja im. Friedricha Eberta, Warszawa 1995. 
The social and economic security in programs of Poland's leftist political ...

[12] Klosko G., Democratic Procedures and Liberal Consensus, Oxford University Press, New York 2003.

[13] Langguth G., In Search of Security. A Socio-political Portrait of Today's Germany, Praeger Publishers, Westport, CT 1995.

[14] Markowska E., Szostak M. (edit.), Państwo wobec zacofania i rozwoju, SGH, Warszawa 1991.

[15] Program Społeczno-Gospodarczy Socjaldemokracji Rzeczypospolitej Polskiej (Social-Economic Program of the Social Democracy of the Republic of Poland), Warszawa - Maj 1991.

[16] SkarzyŃski R., Liberałów polskich siedem grzechów głównych, [in:] Res Publica - Nowa, nr 2, 1994.

[17] SLD, Nasz program dla Polski (SLD, Our Program for Poland), Warszawa - May 1993.

[18] SŁodkowska I., Programy partii i ugrupowań parlamentarnych 1989-1991 [part 1 \& 2], Instytut Studiów Politycznych PAN, Warszawa 1995.

[19] Uchwała Programowa przyjęta przez Pierwszy Kongres Unii Pracy (Program Decree approved by The First Congress of Labor United), Warszawa - January 1993.

\section{BEZPIECZEŃSTWO EKONOMICZNE ORAZ SPOŁECZNE POLSKI W PRO- GRAMACH LEWICOWYCH PARTII POLITYCZNYCH W LATACH 90. XX WIEKU}

Streszczenie: Artykuł ma charakter retrospektywny. Autorzy ukazuje stanowiska lewicowych partii politycznych w kwestii przebudowy systemu ekonomicznego Polski w początkowym okresie transformacji. Analizuje pomysły tych ugrupowań dotyczące bezpieczeństwa gospodarczego oraz społecznego Polski. Artykuł charakteryzuje się tym, że baza źródłowa jest świadomie ograniczona do dokumentów i publikacji będących jak najbardziej zbliżonych czasowo do opisywanych wydarzeń, a niektóre z źródeł stanowią wręcz kronikarski zapis ówczesnych koncepcji. Pozwala to na indywidualną ocenę tych procesów, unikając zarazem licznych dzisiejszych ocen i analiz dotyczących opisywanego okresu. W rzeczy samej, niektóre źródłowo podjęte tematy są chronologiczne w stosunku do rozwijających się treści i zainteresowań. W opinii autorów, takie podejście umożliwia metodyczną ewaluację opisywanych procesów na bazie opisywanych faktów, ukazanych całościowo i syntetycznie. Umożliwia to równocześnie obserwację procesów i skutków przemian. W tym sensie właśnie problematyka bezpieczeństwa narodowego ukazana jest przez determinanty, które bazują na odpowiednim fundamencie, w tym wypadku społeczno-politycznym.

Słowa kluczowe: polityka, bezpieczeństwo, bezpieczeństwo społeczne, bezpieczeństwo ekonomiczne, partie polityczne, socjaldemokracja. 
